\title{
Ketoprak, Cultural Heritage, and Character Building
}

\author{
Budi Waluyo $^{1}$, Dewi Pangestu Said ${ }^{2}$, and Favorita Kurwidaria ${ }^{3}$ \\ \{budiwaluyo@staff.uns.ac.id ${ }^{1}$,dewips@staff.uns.ac.id²,favorita@staff.uns.ac.id ${ }^{3}$ \} \\ 1,2,3 Javanese Education Department, Faculty of Teacher Training and Education, Universitas \\ Sebelas Maret, Indonesia
}

\begin{abstract}
Ketoprak, as one of the traditional performing arts, is highly potential to be reactualized, reconstructed, and refunctionalized. Ketoprak always adjusts itself to the audiences" "taste" in order to preserve and inherit it to the next generation. This preserverance is important since ketoprak is closely related to character building in schools which eventually ketoprak can improve the educational quality within the schools in terms of the students' character quality; holistic, integrated, and balanced. This research aims to describe ketoprak as cultural heritage and describe the character building values within it. The method used was descriptive qualitative. In this research, the qualitative data were thoroughly and analytically described. The range of description includes the development of ketoprak as well as ketoprak as cultural heritage and character building. The findings of the research show that ketoprak is one of the cultural heritage to which perseverance has to be done, for the character building values are rich within it. Implication of this research is that there are efforts from many parties to preserve ketoprak as cultural heritage and a means of character building which are important for society.
\end{abstract}

Keywords: ketoprak, character building, cultural heritage.

\section{INTRODUCTION}

Ketoprak is a long-standing traditional performing art with great potential to be the subject of reactualization, restructure, and refunctioning in this modern days. The longevity and potential of ketoprak are due to the dynamism and flexibility of ketoprak itself compared to the other performing art. Ketoprak is flexible and open towards changes even in the point of replacing several irrelevant elements. This is one of factors that make ketoprak able to last up to these days[1]. It grows and develops in the eastern and southern parts of Central Java which includes the areas of Rembang, Blora, Purwodadi, Kudus, Demak, Pati, and Solo [2].

The history of ketoprak began in around 1925 and performed firstly by a group named Perkumpulan Ketoprak Krido Madyo Utomo from Solo, which was widely known as Kethoprak Lesung. Their move, in 1928, inspired a wayang orang (human puppet) group Bekso Langen Wanodyo, under the lead of Mbok Kertonoyo from Solo, to change their performance from wayang orang to ketoprak. This group is the first ketoprak group with women as the members. The further development brought by a new ketoprak group named Krido Mudo in 1929 in Yogyakarta. They did not use lesung, kentongan, rebana, or western 
instruments, instead they used Javanese instruments, gamelan. The sounds tong-tong from kentongan was changed with keprak. Keprakan is produced by the sound of keprak, which is the arrangement of four metal plates each having 6,2,3, and 1 pitches hanging on the puppet box ...'[3]. These movement was carried out with the aim of giving instructions to the actors, dancers and musicians in the show.

In 1931, a new ketoprak group was established and led by Sosroganjur in Dagen. A year later, again, a new group emerged named Mardi Wandowo. Post G30S PKI emerged several traveling ketoprak groups, such as Dahono Mataram, with new name Waringin Dahono; Wiro Budoyo, and Budi Rahayu. In Yogyakarta, around 1971, Bagong Kussudiarjo established a group nemaed Kethoprak Mataram Sapta Mandala Kodam VII (now Kodam IV). After that, in 1985, several groups emerged in several cities, for example Jati Budaya Pimpinan Gepeng (the next generation of Cokrojio led by Teguh) in Solo, Ngesti Pandowo and Sri Wanita, which was actually a wayang orang group but also performed ketoprak once a week, in Semarang; and Gaya Baru Siswo Budoyo led by Ki Siswando Hardjosuwito in Tulungagung.

In 2000s, after the existence of ketoprak begin to margined by modernityand technology, emerged a new concept and apporach of ketoprak called ketoprak humor, focused on the humour aspect, which was played firstly by Sami Aji (a group with many Srimulat members in it). This group was quite popular, though there was language shift from Javanese to Javanese and Bahasa mixture. The underlying reason was that this group obtained a routine promising support from private parties like private televisions. The research method used in this research was descriptive qualitative. This method was chosen as per to the problems formulation. In this research, the qualitative information were described thoroughly and analytically.

The aspects being described includes the development of ketoprak as well as ketoprak as cultural heritage and character building. This qualitative research deals with characteristical, unique, and multi interpretable data. It is in line with Bodgan and Taylor, who state that qualitative method is a research procedure which results descriptive data obtained from spoken and/or written sources and it can be obtained from attitude of the subjects[4], in this research are the historical, cultural heritage, and character building values. The approach used in this research was descriptive qualitative. This approach was used to describe ketoprak deeply in the relation with the society. This is based on the assumption that essentially, ketoprak is the embodiment of the society itself.

\section{METHOD}

This research is qualitative descriptive. The main focus in this research is to describe and explain in depth about the ketoprak as cultural heritage of Javanese culture can use as media to build character of student. The data were taken from several stages of ketoprak in Central Java. Techniques of data collection was by using techniques refer and recorded some transformation points in ketoprak performances among students. In addition, the authors also conducted interviews with several students who became ketoprak players. Data analysis used flow models of analysis, with stages of data analysis are data reduction, data presentation, and drawing conclusions. To test the validity of data, triangulation technique data was used, namely triangulation of data sources and triangulation theory. 


\section{RESULT AND DISCUSSION}

\subsection{Ketoprak as Culture Heritage}

Indonesia is culturally rich and the cultures are continuously passed down from generation to generation. "Culture can be described as a system of knowledge, beliefs, procedures, attitudes, and artifacts that is shared within a group"[5]. Several temples, dances, house shapes, traditional clothes, and social system are the forms of cultural legacy. This inheritance contains cultural values that become the principles of the people. "In practice, the cultural values result in obedience to superiors (manut), generosity, conflict avoidance, understanding of others, and empathy" [6].

Javanese society's culture can be used as a guideline in establishing community relations, for example how to talk to older people, people with higher social status, and conversely. "However, there were few studies that discussed high and low social class issue especially in Java through Javanese performing art, or Javanese play called Kethoprak'[7]. Of course ketoprak isn't only able to display high and low social class issues but also able to display other moral values that really exist in society.

As we know, ketoprak is also included in the cultural heritage. In 2003, UNESCO divided Cultural Heritage $(\mathrm{CH})$ into material and cultural heritage $(\mathrm{MCH})$ and Intangible cultural heritage, so as to expand the range of $\mathrm{CH}$ to the spiritual and cultural fields[8]. Ketoprak is a non-physical cultrual heritage. Ketoprak is one of the traditional plays. As a play, ketoprak also includes play elements like plot, characterization, dialogue, setting, theme, and moral value[9]. But, how come ketoprak can be long lasting until now? The changes of performances and concepts can be seen on the following aspects and expoundings. First, ketoprak is flexible performing art that can be played in many situations. Ketoprak nowadays is more practical, so a ketoprak performance does not need complex rehearsal and equipments anymore.

Ketoprak performance, in this era, is simplified in terms of the performance as per to the abilities of each member of the group. Second, detailedly, since the emergence of ketoprak for the first time until now, shifts from both on the preparational and performance aspects have always occurred. Despite the simplicity in the performance, ketoprak still pays attention to the tastes of the audience. There are some updates in the ketoprak performance rather than eliminating some elements[10]. We can observe, the first appearance of ketoprak that uses tetabuhan, like a lesung (mortar), a rebana (tambourine) and a flute, has undergone significant changes each period, until finally using complete Javanese gamelan. These days, stage management in ketoprak shows is better and more attractive to the audience. Every element in the show is thought out in detail and organized. "Elements of ketoprak staging are not only players, musicians, and the director, but also lighting crew, setting arrangers, property designers, sound system director, and costume and make-up crew"[10]. Third, the play preformed has undergone a remarkable changes. From very simple plays (peasants' slice of life) into very complex plays, for example the stories of the kingdoms in Java (Majapahit, Blambangan, Demak, Mataram, and the other kingdoms) as well as stories from foreign countries. Fourth, starting in the 2000s, when the need for public as spectactors had focused on art as a fresh and dynamic entertainment, ketoprak humor ketoprak experienced a period of glory. The audience was spoiled with this entertainment. The concept that frees the language, character, attitude, and performance makes the audience feel truly "free" in giving appreciation. In other words, a director has to be capable to read the audiences' tastes in order to make ketoprak survive as an spectacle [11]. 
In order to realize ketoprak as cultural heritage, the artists have done several attempts. It is not an easy to matter to realize ketoprak as an adiluhung (noble) cultural heritage. Art is verily created in line with the advancement of era. For this time, in the midst of life with complex economic problems, the function of art which at first was as a custom, or ritual perhaps, has shifted into a medium or means of entertainment. People see art as an entertaining spectacle, which can forget them from workloads and economic problems.

Some ketoprak groups, in order to inherit it to the people, changed the concept of ketoprak by bringing ketoprak closer to the people. In other words, the ketoprak groups do not wait for the audience to come to them, instead they who come to the people. They hold performances in the middle of the people. The stage can be in the village hall, in the residents' house, at the village intersection, in the pos ronda (village patrol post) and the other common places. Some prominent groups (although not yet in national scale) include Thoprak Pendapan group led by Hanindawan and Ketoprak Ngampung led by Mustanto and Tatak. Both of these groups are from Solo.

They also change the way they perform and the location of the show. They do not focus on performing in an art building, but "visit" the audience themselves. The concept of "visiting" has many advantages, including the possibility that they will not be left behind by the audience, because the audience will be respectful of their arrival by seeing the performance until it ends. The story concept also undergoes transformation and shift. This group shows the concept of a flexible story. Sometimes the ending is "anything" they like. They make their own stories, but sometimes use a carangan (fiction or a compilation of existing stories). Similarly, the concept of gamelan also changes. Not always do they use complete Javanese gamelan, but only a few gamelan based on their needs including the gendhing (songs), which sometimes uses children's songs, pop songs, or national songs suitable to the concept of the story. These changes provide a new aesthetic sense.

Additionally, they also innovate on how to communicate. Crisp talks are use not only in the dialogues but sometimes in interacting with the audiences. This kind of interaction between players and audiences make the performance feel intimate. Besides concept of "visiting" another concept that is also used; it is "free charge." By not charging the audiences, people become more daring to invite them to perform, even though the funds they have are at the lowest. The efficacy of these two concepts are truly felt by Ngampung and Toprak Pendhapan groups. They always travel village to village, sometimes also fulfill invitations to perform in a certain place without taking into account compilcated financial aspects. For them, as long as there is enough fund to hold a performance is enough.

The establishment of Ketoprak Ngampung was underlined by the concerns of Kethoprak Ngampung Surakarta group on the lack of appreciation from the younger generation towards ketoprak. They see there is only a few young people who still want to conserve ketoprak whether as a profession or just merely a hobby. The effort to inherit ketoprak is not only done by the artists, but also schools and colleges. Nowadays, high school students (general and vocational) and undergradates also try to preserve ketoprak as a cultural heritage. Besides, as a form of preservation of Javanese culture, the inclusion of ketoprak in the school and university can be used as a medium conveying the cultural moral values to the audience. "Most students, when it comes to drama in the classroom, instinctively respond to one another through their roles bringing about the nature of creative drama activities which can be considered to be an improvisation tool to imagine, perform, and reflect upon human experience"[12]. Drama in education is also a method that strengthens the individual's communication with himself/herself[13]. 
Fortunately, students and undergraduates assume that traditional performing arts, both Javanese drama and kethoprak, do not only belong to the elderly. The sense of responsibility begins to drive them perserving Javanese traditional performing arts, especially ketoprak. In the past, students and undergraduates considered that perfomring ketoprak requires complex preparation. Besides the actors need to perfrom with Javanese, they also have to compose the music, most of which use gamelan which not every student can play. However, fortunately, time to time, now high school students and undergraduates have become more proficient in performing ketoprak since now gamelan is available in every school and campus as well as a coach ready to train them.

Ketoprak competitions or festivals have become popular. In recent years, in various cities and regencies, ketoprak festivals are often held. In Klaten and in Surakarta, there are annual ketoprak festivals among sub-districts. Not to mention, in some regions also held a ketoprak festival between schools and colleges. Additionally, city and university officials also eagerly want to perform ketoprak as the effort to nguri-uri (preserve) Javanese culture. These efforts are the underlying reasons why ketoprak is long lasting.

\subsection{Ketoprak as a Source of Character Building}

Utilizing literary, artistic and cultural works in order to support character building means respecting and preserving ancestral heritage while limiting the influence of foreign cultures because everything contained in it is a cultural treasure[14]. This is suitable with Basuki's opinion that culture, to the New Order government was often reduced to art which was used to show the "national identity"[15]. Therefore, the existence of national and traditional cultures needs to be maintained and supported by the community as well as how ketoprak is used in schools as a means of character building. This traditional art can be a means for character building since Javanese culture is rife wih wisdom[16].

Ketoprak is established from several elements. One of the important elements is the script or scenario. The types of script vary; it ranges from full text script to short scenario with main ideas of the scenario from which the actors improvise by themselves. Bogaerts said that "the dialogues are spoken in contemporary Javanese, and are couched in a typical vocabulary and prosody"[17]. The dialog is chosen by the screenwriter to adjust to the conditions of the community in the ketoprak performance setting.

The frequently used texts in ketoprak are sourced from folklores. Famous and often played folklores are Jaka Tarub, Timun Mas, Ande-Ande Lumut, Rara Jonggrang, and the other folklores. There is also a text that tells about Javanese kingdoms, such as Arya Penangsang, Rara Mendut-Pranacitra, Minak Jingga and the other kingdom stories. Folklores are stories basically told spokenly. The characters and the events told are sometimes believed happening in the past, merely a creation, or people's sightseeing used to deliver certain messages, moral values, or just simply entertainment to the people[18].

Character building values are often showed in a ketoprak show. In Timun Mas story, for example, it is illustrated that Timun Mas was a little girl who, when she becomes adult, she will be taken by Buta Ijo. But Timun Mas does not want to. She tries to fight againts and defeat Buta Ijo. Finally with various weapons and various means, she can defeat Buto Ijo. There are so many character building values that can be taken from Timun Mas. Among them are courage, confidence, cleverness, tenacity, and other values. These values of course give benefit for the audiences of ketoprak.

Another example is the story of Ande-Ande Lumut. Ande-Ande Lumut is said to be a man who is diligent and handsome with good manners. Because of his good looks he is even asked 
by four girls at once, namely Kleting Abang, Kleting Ijo, Kleting Biru, and Kleting Kuning. Although all four girls are beautiful, but he finally chose Kleting Kuning because Kleting Kuning is a diligent, honest and kind girl. From Ande-Ande Lumut story, the character building value can be driven, that a man, although handsome, should not play women. A man must be careful in choosing a wife. Additionally, it also teaches that a woman is not judged by the beauty of her face, but also in manner, honesty, and purity of heart.

In school, teachers can also use literary learning like the story used in ketoprak as a means of character building. Therefore, literary learning does not only end in cognitive aspect, but also on psychomotoric aspect. It is in line with the statement that It is not enough just to provide provisions for young people with basic academic knowledge and skills, but also the world of education must be able to develop their character[19][20].

\section{CONCLUSION}

Ketoprak is a high valued cultural heritage. As a cultural heritage, ketoprak should be maintained and developed for its sustainability. In an effort to maintain and develop ketoprak, various efforts are needed from various parties. Every individual or group that tries to develop this traditional art must be fully supported, because the responsibility for the continuity of Javanese traditional arts is a shared responsibility. Ketoprak is not merely an art that has mere entertainment value. But in it is stored a variety of character values that are useful for humanity.

\section{REFERENCES}

[1] B. Susanto, Kethoprak. Yogyakarta: Kanisius, 1997.

[2] Pujiati, "Aesthetic Value of Wahyu Manggolo's Kethoprak Performance Presenting Mahesa Jenar Series “Alap-Alap Jentik Manis,” Harmonia, vol. 15 (1), p. 46, 2015.

[3] I. N. H. Putra, P. B, and Sunyata, "Keprakan dalam Pertunjukan Wayang Gaya Yogyakarta: Studi Kasus Pementasan Ki Hadi Sugito,” Resital, vol. 15 (2), p. 190, 2014.

[4] H. Sutopo, Metodologi Penelitian Kualitatif: Dasar teori dan Terapannya dalam Penelitian. Surakarta: Universitas Sebelas Maret, 2006.

[5] G. T. Grandon, "Culture, Complexity, and Informing: How Shared Beliefs Can Enhance Our Search for Fitness," Informing Sci. Int. J. an Emerg. Transdiscipl., vol. 16, 2013.

[6] B. Santosa, "The Influences of Javanese Culture in Power of Making Decisionsi Indonesian Universities: Case Studies in MM Programmes," J. Indones. Econ. Bus., vol. 27, p. 226, 2012.

[7] N. G. Shanty, "When Low Class Confronts High Class: an Analysis of 'Petruk' Interpersonal Meaning Through His Speech Functions in Javanese Performing Art 'Kethoprak," Parol. J. Linguist. Educ., vol. 4 (1), p. 25, 2014.

[8] M. Cao, S. Zhang, J. Zhao, and Y. Hong, "The Current Status, Problems and Integration of the Protection and Inheritance of China's World Cultural Heritage in the Context of Digitalization The Current Status , Problems and Integration of the Protection and Inheritance of China's World Cultur," in IOP Conf. Series: Earth and Environmental Science, 2018, p. 2.

[9] B. Waluyo, Teori dan Kajian Drama Berbasis Pendidikan Karakter untuk SMA dan Sederajat. Surakarta: Smart Media, 2013.

[10] B. W. Setyawan, K. Saddhono, and A. Rakhmawati, "Sociological Aspects and Local Specificity in the Classical Ketoprak Script of Surakarta Style," J. Lang. Lit., vol. 17 (2), p. 145, 2017. 
[11] S. Endraswara, Metode Pembelajaran Drama. Yogyakarta: CAPS (Center For Academic Publishing Service), 2014.

[12] S. Su, "An Action Research on a School Drama Community Service-Learning Project at Danhai Civic Theater in Taiwan,” Int. J. Humanit. Cult. Stud., vol. 1, no. 4, pp. 491-515, 2015.

[13] O. O. Isyar and C. Akay, "The Use of " Drama in Education " in Primary Schools from the Viewpoint of the Classroom Teachers : A Mixed Method Research," J. Educ. Pract., vol. 8, no. 28, p. 215, 2017.

[14] N. K. Ratna, Peranan Karya Sastra Seni dan Budaya dalam Pendidikan Karakter. Yogyakarta: Pustaka Pelajar, 2014.

[15] R. Basuki, "Panakawan's Discourse of Power in Javanese Shadow Puppet during the New Order Regime : From Traditional Perspective to New Historicism," Kata, vol. 8 (1), p. 83, 2016.

[16] H. B. K. Nindya and T. I. Setyani, "Internalization of Sepi ing pamrih Value in Javanese Families in Sawise Langite Katon Biru Novel Internalization of Sepi ing pamrih Value in Javanese Families in Sawise Langite Katon Biru Novel," in IOP Conf. Series: Earth and Environmental Science, 2018, p. 1.

[17] E. Bogaerts, "The installation of Prince Mangkubumi," Wacana, vol. 17, no. 3, p. 477, 2016.

[18] N. N. Karmini, Teori Pengkajian Prosa, Fiksi dan Drama. Denpasar: Pustaka Larasan, 2011.

[19] F. Wardani, Suparmi, and N. S. Aminah, "Evaluating the E-Learning on Students , Character: Blended Learning Model as a Strategy to Improve Students' Character," in Journal Of Physics: Conference Series, 2019, p. 1.

[20] K. Saddhono, S. T, Widodo, M. T. Al Makmun, and M. Tozu, "The study of philosophical meaning of batik and kimono motifs to foster collaborative creative industry." Asian Soc. Sci. vol. 10 no. 9 pp 52-61, 2014 